\title{
Glyphosate Effects on Sugarcane Metabolism and Growth
}

\author{
Caio Antonio Carbonari, Giovanna Larissa Gimenes Cotrick Gomes, \\ Edivaldo Domingues Velini, Renato Fernandes Machado, Plinio Saulo Simões, \\ Gabrielle de Castro Macedo \\ Department of Crop Science, College of Agricultural Sciences, São Paulo State University (UNESP), Botucatu, \\ Brazil \\ Email: carbonari@fca.unesp.br
}

Received 14 October 2014; revised 10 November 2014; accepted 20 November 2014

Copyright (C) 2014 by authors and Scientific Research Publishing Inc.

This work is licensed under the Creative Commons Attribution International License (CC BY). http://creativecommons.org/licenses/by/4.0/

(c) (i) Open Access

\begin{abstract}
Glyphosate is the most widely used herbicide in the world. In sugarcane, it is used as a herbicide when applied at its field rate, but it is also used as ripener when applied as low doses. However, the effects of glyphosate on plant metabolism and sugarcane growth are not fully understood. This study aimed to evaluate the metabolic changes and the effects on sugarcane plant growth caused by the application of different doses of glyphosate. Sugarcane plants were grown in a greenhouse and subjected to glyphosate applications at doses of $7.2 ; 18 ; 36 ; 72 ; 180 ; 360$ and $720 \mathrm{~g} \mathrm{a.e.} \mathrm{ha-1.}^{-1}$. Plants grown without an herbicide application were used as a control. Plants from each treatment were collected at 2, 7, 14, and 21 days after treatment (DAT) application to quantify the levels of shikimic acid, quinic acid, shikimate-3-phosphate, glyphosate, $\alpha$-amino-3-hydroxy-5-methyl-4isoxazolepropionic acid (AMPA), phenylalanine, tyrosine, and tryptophan. Visual evaluations of plant intoxication were performed at the same time as the collection of plants, and the quantification of their shoot dry biomass was performed at 21 DAT. At doses of glyphosate greater than $72 \mathrm{~g}$ a.e. ha $^{-1}$, increases in the levels of shikimic acid, quinic acid, and shikimate-3-phosphate occurred and AMPA was detected in the plants. Initially, glyphosate caused increases in the plant levels of phenylalanine and tyrosine at doses of 72 and $180 \mathrm{~g}$ a.e. ha- ${ }^{-1}$, although a decrease in the levels of aromatic amino acids subsequently occurred at and above the doses of 72 or $180 \mathrm{~g}$ a.e. ha ${ }^{-1}$. The doses ranging from 7.2 to $36 \mathrm{~g}$ a.e. ha ${ }^{-1}$ promoted an increase in plant shoot biomass, and doses greater than $72 \mathrm{~g}$ a.e. $\mathrm{ha}^{-1}$ caused significant reductions in dry mass.
\end{abstract}

\section{Keywords}

EPSPS, AMPA, Shikimic Acid, Herbicide, Sugarcane, Ripener 


\section{Introduction}

Brazil is the world's largest sugarcane (Saccharum spp.) producer, with a planted area of approximately 9.09 million hectares and a mean yield of $72.444 \mathrm{~kg} \cdot \mathrm{ha}^{-1}$ [1]. Sugarcane is a semi-perennial plant requiring a tropical or sub-tropical climate. With a C4 metabolism, this crop has high photosynthetic efficiency and high water use efficiency [2]. The cultivation of sugarcane is one of the best alternatives for the sustainable production of large amounts of biomass that may be converted into various products, especially sugar and ethanol.

Glyphosate plays a key role in global agriculture and in sugarcane cultivation as well because this herbicide is used for managing weeds, for managing the sugarcane ratoon itself, and at low doses, for improving the quality of raw materials by acting as a ripener, stopping flowering and optimizing the maturation potential of sugarcane varieties [3]-[6].

The glyphosate mechanism of action is the enzymatic inhibition of EPSPS (5-enolpyruvylshikimate-3-phosphate (EPSP) synthase, E.C. 2.5.1. 19), which catalyzes the reaction of shikimate-3-phosphate (S3P) with phosphoenolpyruvate (PEP), forming 5-enolpyruvylshikimate-3-phosphate (EPSP) and inorganic phosphorus (Pi) [7]. The enzymatic inhibition of EPSPS by glyphosate affects the shikimic acid metabolic pathway, which generates the three aromatic amino acids phenylalanine, tyrosine, and tryptophan [8].

The shikimic acid pathway, the main pathway for the production of aromatic amino acids, is a metabolic pathway of plants and microorganisms only and is not present in animals [9]. In plants, this pathway is presumably confined to the plastids [10].

These three aromatic amino acids and other intermediate compounds of the shikimic acid pathway are precursors of a wide variety of plant secondary metabolites [11]. Thus, this pathway is eminently important for the synthesis of numerous compounds of commercial interest and also originate various compounds involved in growth regulation or plant defense, especially condensed tannins, anthocyanins, vitamin E, indole acetic acid, salicylic acid, flavones, isoflavones, phenylpropanoids, and coumarins, compounds that are fundamental to plant growth and development [6] [12] [13]. Furthermore, intermediate pathways may produce substrates for other metabolic pathways, including the biosynthesis of quinic acid and derivatives thereof, including chlorogenic acid [9].

The process of regulation of the shikimic acid pathway by glyphosate upon its application to plants is unclear, and it is not known whether the mechanisms of control in various plant species are similar, although the available data indicate they are not similar [13]. A key metabolic alteration triggered in plants upon glyphosate application or drift is the accumulation of shikimic acid. Various authors have been able to correlate glyphosate plant intoxication with shikimic acid accumulation [14]-[21]. Quinic acid, a compound with a similar structure to shikimic acid, can also accumulate in plants exposed to glyphosate [15] [21]-[23]. Thus, this study aimed to evaluate the effects of the application of various glyphosate doses on the metabolic changes and growth of sugarcane plants.

\section{Materials and Methods}

\subsection{Plant Growth and Glyphosate Application}

Stem cuttings of the sugarcane variety SP801842 collected in the field, from an area of cash crops, were planted in pots containing $3 \mathrm{~L}$ of substrate and maintained in a greenhouse. Sugarcane plants received an application of the herbicide glyphosate when they had six fully expanded leaves. In a controlled environment (laboratory), a boom sprayer equipped with four XR 11002 VS nozzles, spaced $0.5 \mathrm{~m}$ apart, and placed $0.5 \mathrm{~m}$ above the plants was used for applications. The working pressure of the device was $2.0 \mathrm{kgf} \cdot \mathrm{cm}^{-2}$, with a $3.6 \mathrm{~km} \cdot \mathrm{h}^{-1}$ speed and a $200 \mathrm{~L} \cdot \mathrm{ha}^{-1}$ consumption of spraying volume. The glyphosate doses of 7.2, 18, 36, 72, 180, 360, and $720 \mathrm{~g}$ a.e. $\mathrm{ha}^{-1}$ were applied, and control plants were maintained without receiving an herbicide application. Treatments were arranged in a completely randomized design with four replicates.

\subsection{Plant Evaluation and Sample Collection}

All leaves from a single plant per replicate of each treatment were collected at 2, 7, 14, and 21 days after treatment (DAT) application, always at the same time. The plant material was washed three times in $50 \mathrm{~mL}$ of distilled water following collection to remove any herbicide residues that were deposited on leaves and unabsorbed.

All plant material was stored in paper bags and dried in a forced-air oven at $40^{\circ} \mathrm{C}$ for 72 hours. The samples 
were then stored in an ultrafreezer $\left(-80^{\circ} \mathrm{C}\right)$ for the subsequent extraction and quantification of compounds.

Visual evaluations of plant intoxication were performed at 21 DAT; a score of 0 corresponded to no injury, and that of 100 corresponded to plant death. The dry biomass of plant shoots was quantified at 21 DAT, by weighing after drying in a forced-air oven.

\subsection{Extraction and Quantification of Compounds}

The dried plant material was macerated in a mortar containing liquid nitrogen, and approximately 100 mg of sample was weighed into and stored in a $15 \mathrm{~mL}$ centrifuge tube. Next, $10 \mathrm{~mL}$ of water that had been acidified to $\mathrm{pH} 2.5$ was added to the tube containing the sample [16]. The tubes were stirred to homogenize the dry sample with the water.

The tubes were placed in an ultrasound bath with a 42-KHz ultrasonic frequency for 30 minutes [24]. Subsequently, they were centrifuged at $4000 \mathrm{rpm}$ for 10 minutes at $20^{\circ} \mathrm{C}$. The supernatant was collected and filtered using a $0.45 \mu \mathrm{m}$ Millex HV filter with a $13 \mathrm{~mm}$ Durapore membrane and stored in a $9 \mathrm{~mm}(2 \mathrm{~mL})$ amber glass vial for subsequent quantification by liquid chromatography-tandem mass spectrometry (LC-MS/MS).

The mass spectrometer was a triple quadrupole instrument, and infusions were performed to optimize its conditions, that is, direct injections of $1 \mathrm{mg} \cdot \mathrm{L}^{-1}$ analytical standard solution of each compound were individually introduced into the spectrometer. The ionization source mode (Electrospray ionization, ESI) was chosen based on the infusion procedure, which produces analyte ions in the liquid phase prior to entering the mass spectrometer. The negative ionization mode was used for the following compounds: shikimic acid, quinic acid, shikimate-3-phosphate, glyphosate, and $\alpha$-amino-3-hydroxy-5-methyl-4-isoxazolepropionic acid (AMPA). The positive ionization mode was used for the three aromatic amino acids (phenylalanine, tyrosine, and tryptophan).

A chromatographic column (Gemini $5 \mu$ C18 $110 \AA$ (150 mm $\times 4.6 \mathrm{~mm})$ ) was used to separate the compounds for quantification in the negative ionization mode, and $5 \mathrm{mM}$ ammonium acetate in water (Phase A) and $5 \mathrm{mM}$ ammonium acetate in methanol (Phase B) were used as the mobile phases at a flow rate of $0.5 \mathrm{~mL} \cdot \mathrm{min}^{-1}$. The gradient employed consisted of 0 - 1 minutes 30\% Phase B and 70\% Phase A; 1 - 5 minutes 50\% Phase B and 50\% Phase A; 5 - 8.5 minutes 75\% Phase B and 25\% Phase A; 8.5 - 15 minutes 90\% Phase B and 10\% Phase A; 15 - 18 minutes 30\% Phase B and 70\% Phase A. A Synergi $2.5 \mu$ Fusion RP $110 \AA$ chromatographic column was used to separate the compounds for quantification in the positive ionization mode, with the same mobile phases and flow rates as described for the negative ionization mode. The gradient employed consisted of 0 - 2 minutes 10\% Phase B and 90\% Phase A; 2 - 4 minutes 40\% Phase B and 60\% Phase A; 4 - 12 minutes $95 \%$ Phase B and 5\% Phase A; 12 - 15 minutes 10\% Phase B and 90\% Phase A. The retention times of each compound in the chromatographic column were 3.86 minutes for shikimic acid, 3.79 minutes for quinic acid, 3.58 minutes for shikimate-3-phosphate, 3.10 minutes for glyphosate, 3.69 minutes for AMPA, 9.71 minutes for phenylalanine, 6.84 minutes for tyrosine, and 10.31 minutes for tryptophan.

\subsection{Data Analysis}

The data for the various parameters evaluated were subjected to analysis of variance using the $\mathrm{F}$ test, and the means were compared using the $t$ test $(p \leq 0.05)$. The standard errors of each mean (mean \pm standard error) were assessed. Regression analysis was performed for the glyphosate and AMPA concentration data using a quadratic equation. A logistic equation was used for the shikimic acid, quinic acid and shikimate-3-phosphate concentration and plant intoxication data, and regression analysis was performed for the plant dry mass accumulation data, fitting the Lorentzian model. The regression procedure was performed using Sigma Plot version 13.0 (Systat Software, Inc., Richmond, CA, USA). The regression equations and corresponding parameters are presented in the figures.

\section{Results and Discussion}

The highest levels of glyphosate in leaf tissues were observed at 2 DAT in plants subjected to the dose of 720 $\mathrm{g} \cdot \mathrm{ha}^{-1}$. Over the course of the other periods evaluated, for the $720 \mathrm{~g}$ a.e. $\mathrm{ha}^{-1}$ dose, the level of glyphosate gradually decreased and was very low at 21 DAT; consequently, the levels of AMPA, which is the main metabolite of glyphosate, increased during this time (Figure 1). For doses of $360 \mathrm{~g}$ a.e. ha ${ }^{-1}$ and below, the levels of glyphosate in the plants at 21 DAT were similar to those observed at 2 DAT, which may be related to slower 

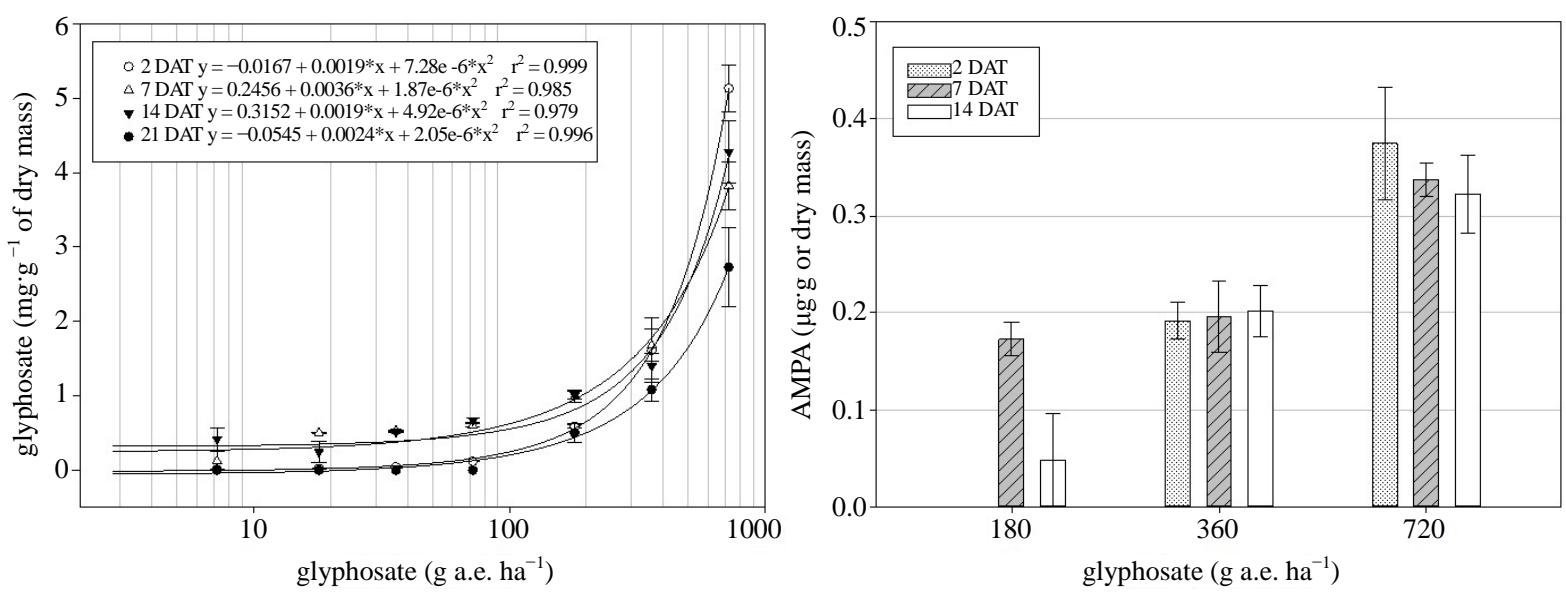

Figure 1. Glyphosate and AMPA concentrations in sugarcane plants (internal) at 2, 7, 14, and 21 days after treatment (DAT) applications of the herbicide glyphosate.

absorption at lower doses, given the lower herbicide concentration in the preparation and the slower rate of diffusion into the leaves, or to greater root exudation at the higher dose as a result of the translocation of greater amounts of herbicide through the plant, or even to the metabolism of glyphosate in the plants.

The presence of AMPA (Figure 1) was only detected at doses greater than $72 \mathrm{~g}$ a.e. ha ${ }^{-1}$, and the plant concentrations of AMPA increased starting at this dose. There were no significant differences among the periods evaluated, except at the dose of $180 \mathrm{~g} \cdot \mathrm{ha}^{-1}$ at 7 DAT. The presence of AMPA may be related to the metabolism of the glyphosate herbicide in sugarcane plants or to the absorption of AMPA metabolite present on the surface of leaves as the result of epiphytic microbial degradation of glyphosate [17]. The detection of AMPA in leaves, stems, and seeds from various crops, including soybean resistant to glyphosate, following its application suggests that glyphosate oxidoreductase (GOX) or a similar type of enzyme catalyzes this reaction [17] [25] [26].

No increases in the plant levels of shikimic acid were observed in plants at or under the dose of $72 \mathrm{~g}$ a.e. ha ${ }^{-1}$ for any period evaluated when compared to non-treated plants (Figure 2). Accumulations of shikimic acid were observed above that dose and the greatest accumulations of shikimic acid, corresponding to the doses tested, were observed at 2 DAT, which was the best time to characterize sugarcane plant intoxication by glyphosate. A similar performance to that observed in this study was also reported for young and adult Citrus limonia leaves in which shikimic acid had accumulated to high concentrations at 2 DAT and then subsequently decreased in concentration, indicating a transient effect of the herbicide at sublethal doses [27]. Other authors have reported that the shikimic acid level following glyphosate application may change with time, as noted for young Abutilon theophrasti leaves [28], wheat grains [29], and horseweed leaves [30].

The sugarcane plants did not accumulate high levels of shikimic acid, even at the dose of $720 \mathrm{~g}$ a.e. ha ${ }^{-1}$, which indicates that this dose was not sufficient to cause high levels of injury to these plants and characterizes them as highly tolerant to the herbicide glyphosate. In contrast, shikimic acid accumulated rapidly in adult Beta vulgaris $\mathrm{L}$. leaves, reaching a concentration 80 -fold greater than the control by 24 hours following the application [31]. High shikimic acid concentrations have been recorded in several studies, including $0.17 \mathrm{mg} \cdot \mathrm{g}^{-1} \mathrm{of} A$. theophrasti dry mass following the application of glyphosate [32], an increase in the shikimic acid concentration from 0.4 to $40 \mu \mathrm{mol} \cdot \mathrm{g}^{-1}$ fresh mass (100-fold increase) in young leaves of soybean non-resistant to glyphosate, and an increase from 0.4 to $12.8 \mu \mathrm{mol} \cdot \mathrm{g}^{-1}$ (32-fold increase) in maize non-resistant to glyphosate [33].

The concentrations of quinic acid also changed in the shikimic acid pathway at doses of $72 \mathrm{~g}$ a.e. ha ${ }^{-1}$ and above (Figure 2). This compound followed a similar pattern as shikimic acid, although it was a less sensitive indicator of glyphosate intoxication than the former. High correlations between the levels of shikimic and quinic acids and glyphosate in maize plants have been reported, indicating that quinic acid can be a good indicator of glyphosate-intoxicated plants [34].

Apparently, quinic acid may act as a reserve compound in the shikimic acid pathway, although its physiological role is not completely understood [15]. A 1.4-fold quinic acid accumulation in pea leaves (Pisum sativum L.) at 15 days after treatment with glyphosate was observed [15] because of the accumulation of compounds in the shikimic acid pathway, and a similar result was observed for shikimic acid, protocatechuic acid, and gallic acid 

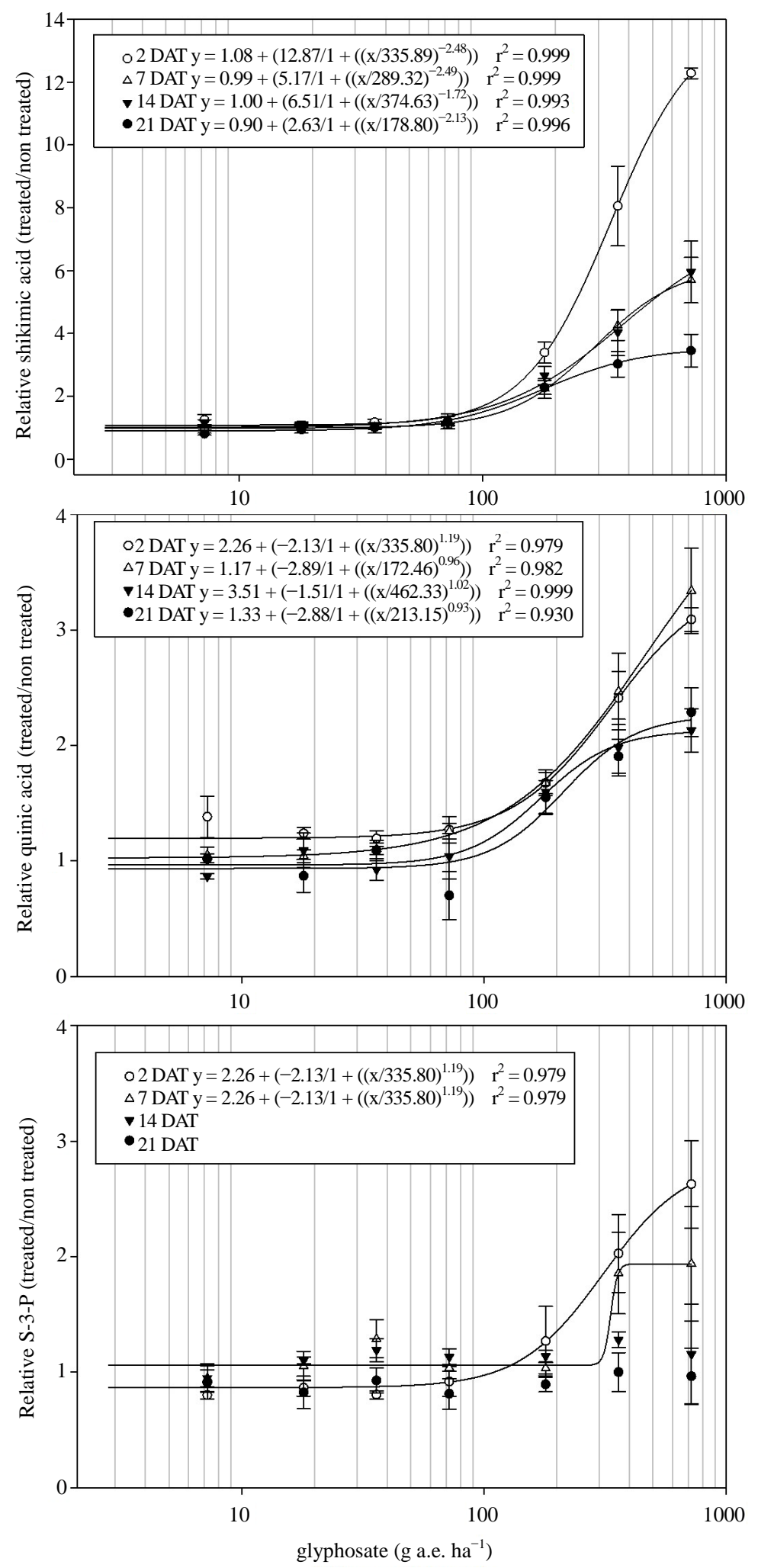

Figure 2. Relative (treated/non-treated) concentrations \pm the standard error of shikimic acid, quinic acid, and shikimate-3-phosphate in sugarcane plants 2, 7, 14, and 21 days after applying various doses of glyphosate (days after treatment, DAT). 
[15]. Similarly, shikimate-3-phosphate had accumulated at 2 and 4 days after the application of doses greater than $72 \mathrm{~g}$ a.e. $\mathrm{ha}^{-1}$ because this compound is the substrate directly used in the reaction catalyzed by EPSPS (Figure 2). The quinic acid and shikimate-3-phosphate acid exhibited dynamics very similar to those of shikimic acid in sugarcane plants, although the relative increases were smaller.

The levels of phenylalanine and tyrosine had increased compared to the control at 2 DAT for the glyphosate dose of $360 \mathrm{~g}$ a.e. $\mathrm{ha}^{-1}$, and there was a nearly 2-fold increase in these amino acids relative to the control at the glyphosate dose of $72 \mathrm{~g}$ a.e. $\mathrm{ha}^{-1}$ (Table 1). The correlation between the phenylalanine and tyrosine levels in the leaf tissue may be related to the formation of these two amino acids from the same precursor, prephenate, following the branching of the shikimic acid pathway. There were small variations in tryptophan in plants subjected to various doses of glyphosate during this same period, and the levels of tryptophan were greater than or equal to the control at the majority of doses (Table 1). A possible explanation for this observation is that tryptophan is the aromatic amino acid that is least sensitive to glyphosate inhibition [34]. Compared to non-treated plants, an increase in tryptophan concentration was observed in Cyperus rotundus seedlings 3 DAT with glyphosate [35]. The levels of aromatic amino acids were analyzed in Nicotiana plumbaginifolia cells 4 days after supplementing the culture media with $100 \mu \mathrm{M}$ glyphosate, and decreases of 59\% and 77\% in the tyrosine and phenylalanine concentrations, respectively, were observed, while the tryptophan level only decreased by $13 \%$ [36].

At 14 and 21 DAT, small increases in the concentrations of the 3 aromatic amino acids compared to the controls were observed at the glyphosate doses of $18 \mathrm{~g} \cdot \mathrm{ha}^{-1}$ for tryptophan and $36 \mathrm{~g} \cdot \mathrm{ha}^{-1}$ for the other 2 amino acids (Table 1). Decreasing trends in the levels of the 3 amino acids levels occurred at the dose of $72 \mathrm{~g} \cdot \mathrm{ha}^{-1}$ and

Table 1. Relative (treated/non-treated) concentrations of phenylalanine, tyrosine, and tryptophan in sugarcane plants at 2, 7 , 14 , and 21 days after treatment (DAT) application.

\begin{tabular}{|c|c|c|c|c|}
\hline \multirow{2}{*}{ 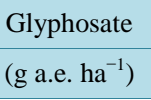 } & \multicolumn{4}{|c|}{ Days after treatment (DAT) } \\
\hline & 2 & 7 & 14 & 21 \\
\hline & \multicolumn{4}{|c|}{ Relative phenylalanine (treated/non-treated) } \\
\hline 7.2 & $1.30 \pm 0.16$ & $0.98 \pm 0.12$ & $1.07 \pm 0.11$ & $0.85 \pm 0.06$ \\
\hline 18 & $1.28 \pm 0.05$ & $0.94 \pm 0.12$ & $1.13 \pm 0.13$ & $1.08 \pm 0.17$ \\
\hline 36 & $1.13 \pm 0.07$ & $1.39 \pm 0.36$ & $1.14 \pm 0.21$ & $1.23 \pm 0.10$ \\
\hline 72 & $1.77 \pm 0.34$ & $0.75 \pm 0.07$ & $0.5 \pm 0.08$ & $1.05 \pm 0.29$ \\
\hline 180 & $1.42 \pm 0.53$ & $0.62 \pm 0.04$ & $0.43 \pm 0.03$ & $0.68 \pm 0.02$ \\
\hline 360 & $1.31 \pm 0.38$ & $0.95 \pm 0.05$ & $0.57 \pm 0.16$ & $0.86 \pm 0.09$ \\
\hline \multirow[t]{2}{*}{720} & $0.93 \pm 0.14$ & $1.01 \pm 0.13$ & $0.55 \pm 0.18$ & $0.71 \pm 0.06$ \\
\hline & \multicolumn{4}{|c|}{ Relative tyrosine (treated/non-treated) } \\
\hline 7.2 & $1.33 \pm 0.16$ & $0.65 \pm 0.09$ & $1.05 \pm 0.16$ & $0.99 \pm 0.07$ \\
\hline 18 & $1.28 \pm 0.09$ & $0.53 \pm 0.04$ & $0.77 \pm 0.08$ & $1.44 \pm 0.42$ \\
\hline 36 & $0.97 \pm 0.06$ & $0.54 \pm 0.02$ & $0.95 \pm 0.17$ & $1.68 \pm 0.17$ \\
\hline 72 & $1.96 \pm 0.29$ & $0.46 \pm 0.03$ & $0.61 \pm 0.08$ & $0.98 \pm 0.20$ \\
\hline 180 & $1.66 \pm 0.49$ & $0.34 \pm 0.03$ & $0.45 \pm 0.02$ & $0.61 \pm 0.05$ \\
\hline 360 & $1.34 \pm 0.32$ & $0.55 \pm 0.02$ & $0.50 \pm 0.15$ & $0.78 \pm 0.14$ \\
\hline \multirow[t]{2}{*}{720} & $0.80 \pm 0.09$ & $0.54 \pm 0.05$ & $0.56 \pm 0.12$ & $0.87 \pm 0.15$ \\
\hline & \multicolumn{4}{|c|}{ Relative tryptophan (treated/non-treated) } \\
\hline 7.2 & $1.18 \pm 0.11$ & $0.86 \pm 0.07$ & $1.10 \pm 0.15$ & $1.00 \pm 0.12$ \\
\hline 18 & $1.10 \pm 0.07$ & $1.11 \pm 0.08$ & $1.27 \pm 0.14$ & $1.38 \pm 0.09$ \\
\hline 36 & $0.97 \pm 0.05$ & $1.12 \pm 0.10$ & $1.09 \pm 0.15$ & $1.36 \pm 0.04$ \\
\hline 72 & $1.17 \pm 0.11$ & $0.86 \pm 0.06$ & $0.77 \pm 0.03$ & $1.02 \pm 0.14$ \\
\hline 180 & $1.04 \pm 0.17$ & $0.76 \pm 0.03$ & $0.84 \pm 0.08$ & $0.73 \pm 0.02$ \\
\hline 360 & $1.23 \pm 0.04$ & $0.96 \pm 0.08$ & $0.63 \pm 0.09$ & $0.77 \pm 0.11$ \\
\hline 720 & $1.14 \pm 0.09$ & $0.73 \pm 0.07$ & $0.76 \pm 0.03$ & $0.79 \pm 0.11$ \\
\hline
\end{tabular}


above at 7, 14, and 21 DAT. The levels of phenylalanine and tyrosine slightly increased again at the dose of 180 $\mathrm{g} \cdot \mathrm{ha}^{-1}$ and above, albeit still below the control levels. This slight increase in the levels of amino acids in plant tissues subjected to the greatest doses of glyphosate at 7, 14, and 21 DAT may be related to protein degradation and the release of these amino acids in tissues. Aromatic amino acids are used not only for protein synthesis in plants but also as precursors of a large number of secondary metabolites [12].

A marked increase in the concentration of phenylalanine was reported for Brassica napus plants in response to concentrations of $1 \mu \mathrm{M}$ and $10 \mu \mathrm{M}$ glyphosate, although the concentration tended to decrease to levels lower than in non-treated plants at higher glyphosate concentrations [19]. Although glyphosate is responsible for blocking the biosynthesis of aromatic amino acids, it often fails to produce a clear decrease in the levels of phenylalanine, tyrosine, and tryptophan when the concentrations of plants exposed to glyphosate are compared to the concentrations of control plants.

A transient effect of glyphosate on the total levels of aromatic amino acids was also observed in Citrus limonia plants subjected to various doses of glyphosate, with decreases at 2 DAA and increases starting at 4 DAA, regardless of the glyphosate dose evaluated [27]. A decrease in the levels of aromatic amino acids (the sum of phenylalanine, tyrosine, and tryptophan in relation to total amino acids) occurred in pea plants treated with glyphosate from the first day after the treatment, although the levels of amino acids increased again after this initial transient drop [15].

Plant intoxication symptoms were observed at the doses of $72 \mathrm{~g}$ a.e. $\mathrm{ha}^{-1}$ and above at 21 DAT (Figure 3). The symptoms were very severe at the two highest doses, significantly compromising plant development. In addition, the increases in the levels of shikimic acid, quinic acid, and shikimate-3-phosphate compared to the non-treated plants at the same doses indicates the absence of negative effects in this regard at lower doses.

The dry mass of the plants was significantly reduces at doses of $72 \mathrm{~g}$ a.e. $\mathrm{ha}^{-1}$ and above, and there were signs of injury to leaves (Figure 3). However, plants produced greater biomass compared to the control treatment at doses ranging from 7.2 to $36 \mathrm{~g}$ a.e. $\mathrm{ha}^{-1}$ at 21 DAT. The stimulation of growth of a number of species subjected to low doses of glyphosate has been reported and discussed by various authors [37]-[39]. Glyphosate applications at the dose of $1.8 \mathrm{~g}$ a.e. $\mathrm{ha}^{-1}$ reportedly provided an increase in sugarcane shoot and root dry mass compared to plants that received no glyphosate application [40].

\section{Conclusion}

At doses of glyphosate greater than $72 \mathrm{~g}$ a.e. $\mathrm{ha}^{-1}$, increases in the levels of shikimic acid, quinic acid, and shikimate-3-phosphate occurred, and AMPA was detected in the plants. Initially, glyphosate caused increases in the levels of phenylalanine and tyrosine in plants at doses of glyphosate of 72 and $180 \mathrm{~g}$ a.e. ha ${ }^{-1}$, although a subsequent decrease over time in the levels of these aromatic amino acids occurred at these doses. The doses between 7.2 and 36 g a.e. $\mathrm{ha}^{-1}$ promoted an increase in plant shoot biomass, while doses of glyphosate greater than $72 \mathrm{~g}$ a.e. ha ${ }^{-1}$ caused significant reductions in dry mass.
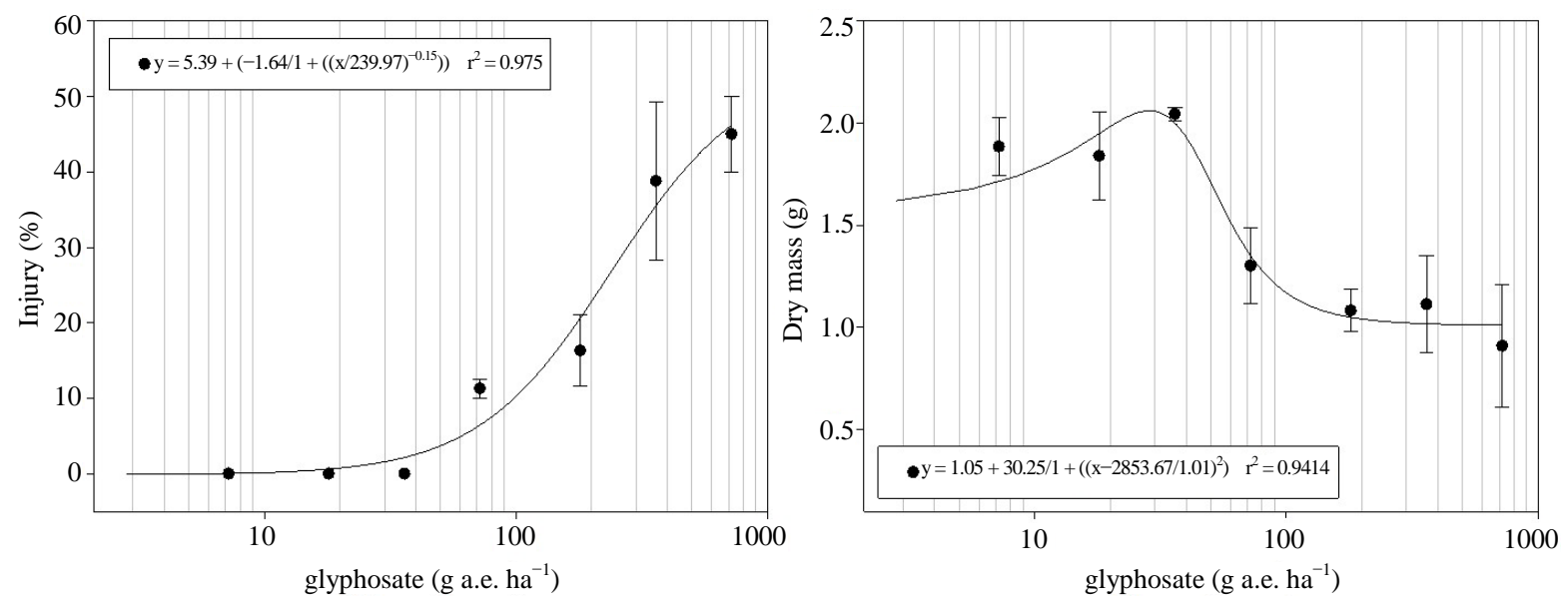

Figure 3. Injury percentages and dry masses of sugarcane plant shoots 21 days after applying various doses of glyphosate (DAT). 


\section{Acknowledgements}

This research was funded by the São Paulo Research Foundation (FAPESP).

\section{References}

[1] CONAB (2014) Acompanhamento da safra brasileira de cana-de-açúcar [Monitoring of the Brazilian Sugarcane Harvest]. Conab, Brasília.

[2] Casagrande, A.A. and Vasconcelos, A.C.M. (2008) Fisiologia da parte aérea. In: Dinardo-Miranda, L.L., Vasconcelos, A.C.M. and Landell, M.G.A., Eds., Cana-de-Açúcar, Instituto Agronômico, Campinas, 57-78.

[3] Silva, M.A., Carlin, S.D. and Caputo M.M. (2006) Tipos de colheita e épocas de aplicação de glifosate na erradicação de ratoons de cana-de-açúcar [Harvest Types and Times of Glyphosate Application in the Eradication of Sugarcane Ratoons]. Pesquisa Agropecuária Brasileira, 41, 43-49. http://dx.doi.org/10.1590/S0100-204X2006000100007

[4] Netto, J.M. (2006) Maturatores e reguladores vegetais na cultura da sugarcane [Maturators and plant growth regulators of the sugarcane crop]. In: Egato, S.V., Pinto, A.S. Jendiroba, E. and Nóbrega, J.C.M., Eds., Atualização em produção de cana-de-açúcar [Update on the Sugarcane Production], CP, Piracicaba, 307-318.

[5] Meschede, D.K., Sanomya, R., Carbonari, C.A. and Velini, E.D. (2011) Respostas fisiológicas da cana-de-açúcar ao uso do glyphosate como maturador [Physiological Responses of Sugarcane to the Use of Glyphosate as a Ripener]. In: Velini, E.D., Meschede, D.K., Carbonari, C.A. and Trindade, M.L.B., Eds., Glyphosate, Fepaf, Botucatu, 445-459.

[6] Velini, E.D., Trindade, M.L.B., Barberis, L.R.M. and Duke, S.O. (2010) Growth Regulation and Other Effects of Herbicides. Weed Science, 58, 351-354. http://dx.doi.org/10.1614/WS-D-09-00028.1

[7] Franz, J.E., Mao, M.K. and Sikorski, J.A. (1997) Glyphosate: A Unique Global Herbicide. ACS monograph, Washington DC.

[8] Duke, S.O. (1988) Glyphosate. In: Kearney, P.C. and Kaufman, D.D., Eds., Herbicides: Chemistry, Degradation, and Mode of Action, Dekker, New York, 1-70.

[9] Herrmann, K.M. and Weaver, L.M. (1999) The Shikimate Pathway. Annual Review of Plant Physiology and Plant Molecular Biology, 50, 473-503. http://dx.doi.org/10.1146/annurev.arplant.50.1.473

[10] Weber, A.P.M., Schwacke, R. and Flugge, U.I. (2005) Solute Transporters of the Plastid Envelope Membrane. Annual Review of Plant Biology, 56, 133-164. http://dx.doi.org/10.1146/annurev.arplant.56.032604.144228

[11] Dewick, P.M. (1998) The Biosynthesis of Shikimate Metabolites. Natural Products Reports, 15, 17-58. http://dx.doi.org/10.1039/a815017y

[12] Herrmann, K.M. (1995) The Shikimate Pathway: Early Steps in the Biosynthesis of Aromatic Compounds. The Plant Cell, 7, 907-919. http://dx.doi.org/10.1105/tpc.7.7.907

[13] Velini, E.D., Carbonari, C.A., Trindade, M.L.B., Gomes, G.L.G.C., Meschede, D.K. and Duke, S.O. (2011) Modo de ação do Glyphosate [Glyphosate Mechanism of Action]. In: Velini, E.D., Carbonari, C.A., Meschede, D.K. and Trindade, M.L.B., Eds., Glyphosate, Fepaf, Botucatu, 39-66.

[14] Reddy, K.N., Bellaloui, N. and Zablotowicz, R.M. (2010) Glyphosate Effect on Shikimate, Nitrate Reductase Activity, Yield, and Seed Composition in Corn. Journal of Agricultural and Food Chemistry, 58, 3646-3650. http://dx.doi.org/10.1021/jf904121y

[15] Orcaray, L., Igal, M., Marino, D., Zabalza, A. and Royuela, M. (2010) The Possible Role of Quinate in the Mode of Action of Glyphosate and Acetolactate Synthase Inhibitors. Pest Management Science, 66, 262-269. http://dx.doi.org/10.1002/ps.1868

[16] Matallo, M.B., Almeida, S.D.B., Cerdeira, A.L., Franco, D.A., Blanco, F.M.G., Menezes, P.T.C., Luchini, L.C., Moura, M.A.M. and Duke, S.O. (2009) Microwave-Assisted Solvent Extraction and Analysis of Shikimic Acid from Plant Tissues. Planta Daninha, 27, 987-994. http://dx.doi.org/10.1590/S0100-83582009000500012

[17] Reddy, K.N., Rimando, A.M., Duke, S.O. and Nandula, V.K. (2008) Aminomethylphosphonic Acid Accumulation in Plant Species Treated with Glyphosate. Journal of Agricultural and Food Chemistry, 56, 2125-2130. http://dx.doi.org/10.1021/jf072954f

[18] Buehring, N.W., Massey, J.H. and Reynolds, D.B. (2007) Shikimic Acid in Field-Grown Corn (Zea mays) Following Simulated Glyphosate Drift. Journal of Agricultural and Food Chemistry, 55, 819-824. http://dx.doi.org/10.1021/jf062624f

[19] Petersen, I.L., Hansena, H.C.B., Ravn, H.W., Sorensen, J.C. and Sorensen, H. (2007) Metabolic Effects in Rapeseed (Brassica napus L.) Seedlings after Root Exposure to Glyphosate. Pesticide Biochemistry and Physiology, 89, 220-229. http://dx.doi.org/10.1016/j.pestbp.2007.06.009

[20] Feng, C.C., Tran, M., Chiu, T., Sammons, R.D., Heck, G.R. and CaJacob, C.A. (2004) Investigations into Glypho- 
sate-Resistant Horseweed (Conyza canadensis): Retention, Uptake, Translocation, and Metabolism. Weed Science, 52, 498-505. http://dx.doi.org/10.1614/WS-03-137R

[21] Harring, T., Streibig, J.C. and Husted, S. (1998) Accumulation of Shikimic Acid: A Technique for Screening Glyphosate Efficiency. Journal of Agricultural and Food Chemistry, 46, 4406-4412. http://dx.doi.org/10.1021/jf9802124

[22] Ossipov, V.I. and Aleksandrova, L.P. (1982) Spatial Organization of Quinic and Shikimic Acid Biosynthesis in the Autotrophic Cell of Pinus sylvestris Needles. Soviet Plant Physiology, 29, 289-292.

[23] Orcaray, L., Zulet, A., Zabalza, A. and Royuela, M. (2012) Impairment of Carbon Metabolism Induced by the Herbicide Glyphosate. Journal of Plant Physiology, 169, 27-33. http://dx.doi.org/10.1016/j.jplph.2011.08.009

[24] Gomes, G.L.G.C. (2011) Alterações metabóLicas de Plantas de Milho Submetidas à Aplicação de Glyphosate e Fosfito [Metabolic Changes of Maize Plants Subjected to an Application of Glyphosate and Phosphite]. MSC. Thesis, Faculdade de Ciências Agronômicas, Universidade Estadual Paulista, Botucatu [School of Agricultural Sciences, São Paulo State University, Botucatu].

[25] Duke, S.O., Rimando, A.M., Pace, P.F., Reddy, K.N. and Smeda, R.J. (2003) Isoflavone, Glyphosate, and Aminomethylphosphonic Acid Levels in Seeds of Glyphosate-Treated, Glyphosate-Resistant Soybean. Journal of Agricultural and Food Chemistry, 51, 340-344. http://dx.doi.org/10.1021/jf025908i

[26] Arregui, M.C., Lenardón, A., Sanchez, D., Maitre, M.I., Scotta, R. and Enrique, S. (2004) Monitoring Glyphosate Residues in Transgenic Glyphosate-Resistant Soybean. Pest Management Science, 60, 163-166. http://dx.doi.org/10.1002/ps.775

[27] Gravena, R., Victoria Filho, R., Alves, P.L., Mazzafera, P. and Gravena, A.R. (2009) Low Glyphosate Rates Do Not Affect Citrus limonia (L.) Osbeck Seedlings. Pest Management Science, 65, 420-425. http://dx.doi.org/10.1002/ps.1694

[28] Becerril, J.M., Duke, S.O. and Lydon, J. (1989) Glyphosate Effect on Shikimate Pathway Products in Leaves and Flowers of Velvetleaf. Phytochemistry, 28, 695-699. http://dx.doi.org/10.1016/0031-9422(89)80095-0

[29] Bresnahan, G.A., Manthey, F.A., Howatt, K.A. and Chakraborty, M. (2003) Glyphosate Applied Preharvest Induces Shikimic Acid Accumulation in Hard Red Spring Wheat (Triticum aestivum). Journal of Agricultural and Food Chemistry, 51, 4004-4007. http://dx.doi.org/10.1021/jf0301753

[30] Mueller, T.C., Massey, J.H., Hayes, R.M., Main, C.L. and Stewart Jr., C.N. (2003) Shikimate Accumulates in both Glyphosate-Sensitive and Glyphosate-Resistant Horseweed (Conyza canadensis L. Cronq.). Journal of Agricultural and Food Chemistry, 51, 680-684. http://dx.doi.org/10.1021/jf026006k

[31] Geiger, D.R., Tucci, M.A. and Serviates, J.C. (1987) Glyphosate Effects on Carbon Assimilation and Gas Exchange in Sugar Beet Leaves. Plant Physiology, 85, 365-369. http://dx.doi.org/10.1104/pp.85.2.365

[32] Fuchs, M.A., Geigera, D.R., Reynoldsb, T.L. and Bourqueb, J.E. (2002) Mechanisms of Glyphosate Toxicity in Velvetleaf (Abutilon theophrasti Medikus). Pesticide Biochemistry and Physiology, 74, 27-39. http://dx.doi.org/10.1016/S0048-3575(02)00118-9

[33] Singh, B.K. and Shaner, D.L. (1998) Rapid Determination of Glyphosate Injury to Plants and Identification of Glyphosate-Resistant Plants. Weed Technology, 12, 527-530.

[34] Amrhein, N., Deus, B., Gehrke, P. and Steinrücken, H.C. (1980) The Site of the Inhibition of the Shikimate Pathway by Glyphosate.II. Interference of Glyphosate with Chorismate Formation in Vivo and in Vitro. Plant Physiology, 66, 830-834. http://dx.doi.org/10.1104/pp.66.5.830

[35] Wang, C.Y. (2001) Effect of Glyphosate on Aromatic Amino Acid Metabolism in Purple Nutsedge (Cyperus rotundus). Weed Technology, 15, 628-635. http://dx.doi.org/10.1614/0890-037X(2001)015[0628:EOGOAA]2.0.CO;2

[36] Forlani, G., Lejczak, P. and Kafarski, P. (2000) The Herbicidally Active Compound N-2-(5-Chloropyridyl) Aminomethylene Bisphosphonic Acid Acts by Inhibiting both Glutamine and Aromatic Amino Acid Biosynthesis. Australian Journal of Plant Physiology, 27, 677-683.

[37] Schanbenberger, O., Tharp, B.E., Kells, J.J. and Penner, D. (1999) Statistical Tests for Hormesis and Effective Dosage in Herbicide Dose Response. Agronomy Journal, 91, 713-721. http://dx.doi.org/10.2134/agronj1999.914713x

[38] Cedergreen, N., Streibig, J.C., Kudsk, P., Mathiassen, S.K. and Duke, S.O. (2007) The Occurrence of Hormesis in Plants and Algae. Dose-Response, 5, 150-162. http://dx.doi.org/10.2203/dose-response.06-008.Cedergreen

[39] Velini, E.D., Alves, E., Godoy, M.C., Meschede, D.K., Souza, R.T. and Duke, S.O. (2008) Glyphosate Applied at Low Doses Can Stimulate Plant Growth. Pest Management Science, 64, 489-496. http://dx.doi.org/10.1002/ps.1562

[40] Silva, M.A., Aragão, N.C., Barbosa, M.A., Jeronimo, E.M. and Carlin, S.D. (2009) Efeito Hormótico de Gliphosate no Desenvolvimento Inicial de Cana-de-Açúcar [Hormetic Effect of Glyphosate on the Initial Development of Sugarcane]. Bragantia, 68, 973-978. http://dx.doi.org/10.1590/S0006-87052009000400017 
Scientific Research Publishing (SCIRP) is one of the largest Open Access journal publishers. It is currently publishing more than 200 open access, online, peer-reviewed journals covering a wide range of academic disciplines. SCIRP serves the worldwide academic communities and contributes to the progress and application of science with its publication.

Other selected journals from SCIRP are listed as below. Submit your manuscript to us via either submit@scirp.org or Online Submission Portal.
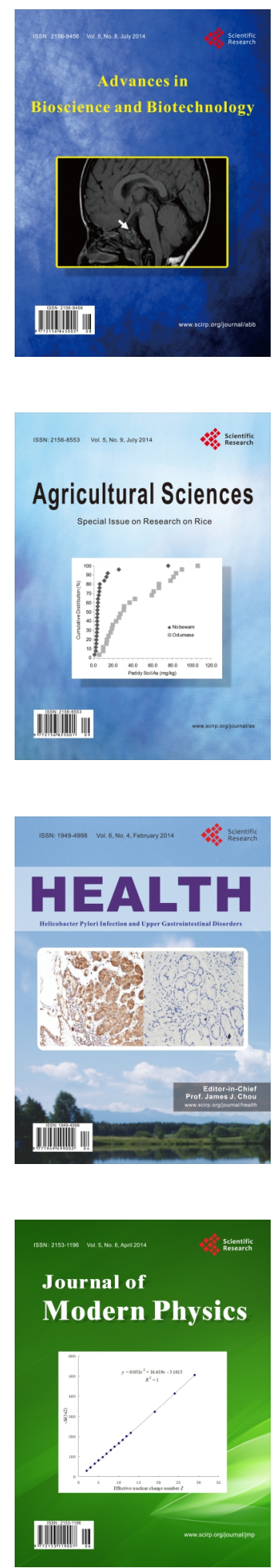
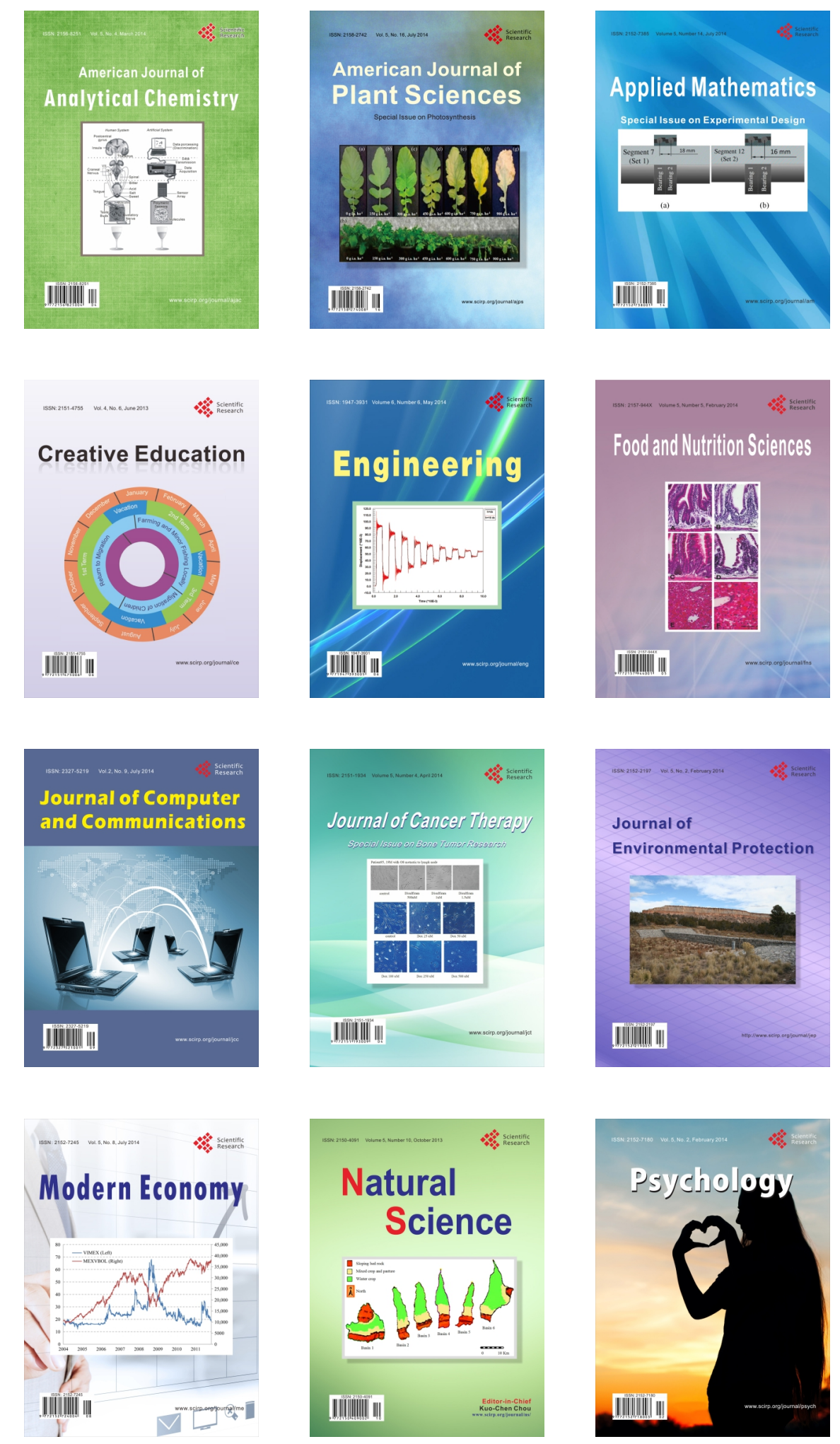